\title{
WILEY

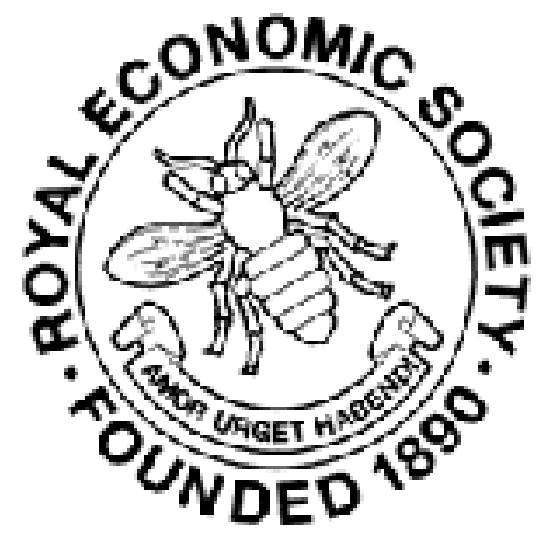

Die Bank von England mit Besonderer Berucksichtigung der Reservefrage und der Entwertung der Englischen Rente. by O. Hulftegger

Review by: Mabel C. Buer

The Economic Journal, Vol. 25, No. 99 (Sep., 1915), pp. 414-417

Published by: Wiley on behalf of the Royal Economic Society

Stable URL: http://www.jstor.org/stable/2221898

Accessed: 11/02/2015 10:30

Your use of the JSTOR archive indicates your acceptance of the Terms \& Conditions of Use, available at http://www.jstor.org/page/info/about/policies/terms.jsp

JSTOR is a not-for-profit service that helps scholars, researchers, and students discover, use, and build upon a wide range of content in a trusted digital archive. We use information technology and tools to increase productivity and facilitate new forms of scholarship. For more information about JSTOR, please contact support@jstor.org.

Wiley and Royal Economic Society are collaborating with JSTOR to digitize, preserve and extend access to The Economic Journal. 
The causes determining the purchasing power of money are set forth with admirable clearness and lucidity; indeed, the style is so concise and the reasoning so compressed, that it is impossible to let the attention wander for a moment without losing the thread of the argument. We have here a very fine example of the possibility of translating mathematical ideas and symbols into vigorous and intelligible prose.

The very slight chapter devoted to the operation of different monetary systems seems hardly worthy of the rest of the book. Perhaps the fact that it is intended primarily for American readers accounts for the omission of any reference to the gold standard or its offspring, the gold-exchange standard. With his powers of exposition Professor Fisher should not find much difficulty in making the operation of the latter system intelligible to the ordinary reader, and it is surely time that the gold-exchange standard should be recognised in general works on money as being one of the great monetary systems of the world.

In an interesting postscript written in August, 1914, the author discusses very briefly the probable effects of the European war on prices. His opinion is that, as England will suffer less actual disturbance of industry during the course of the war than any of the other belligerents, the general level of prices should rise less there than in other countries. But after the war he expects prices to rise more in England than anywhere else.

Finally, at the conclusion of the present volume, Professor Fisher promises another, which is to treat of the standardising of the dollar-a practical problem of great importance, in the working out of which he has already done much valuable and pioneer work.

C. W. Guillebadd

\section{Die Bank von England mit besonderer Berücksichtigung der} Reservefrage und der Entwertung der Englischen Rente. Von Dr. O. Hulftegger. (Zürich : Orell Füseli, 1915. Pp. vii +423 . Price 10 Fr.)

THIs book may be divided into two parts-descriptive and critical. The descriptive portion is a straightforward and clear account of the London Money Market based upon an explanation of the bank return. Dr. Hulftegger is evidently writing primarily for those who have a working knowledge of financial theory, but who are ignorant of the details of the organisation of the London Money Market. The descriptive part of this book will not, therefore, contain a great deal that is fresh to English readers; but the numerous historical notes and statistical 
tables throughout the volume should make it a useful book of reference.

It is in the critical part that the chief interest of the book will be found. While the descriptive section covers practically the whole financial fabric, the critical portion is confined to the subjects of the sub-title, namely the question of the Reserve and the Depreciation of Consols. The preface informs us that the book was finished just before the outbreak of war. The criticisms contained will, therefore, have a permanent value as a record of orthodox opinion upon the Reserve question before the great testing, as the author gives a summary of the opinions advanced and the remedies proposed by leading financial authorities. Indeed, one feels he has been rather too modest and has kept his own opinion too much in the background, and it can often only be gathered by implication.

It is easy to criticise after the event, and those writing now have an unfair advantage over the prophets. But one or two points may perhaps be raised without undue unfairness. For instance, our author seems to consider that the Post Office Savings Bank should keep a gold reserve, especially in view of the nonliquid nature of Consols. He seems to have taken the opinion of Joint Stock Bankers too much at its face value, forgetting that the Joint Stock Banks now eagerly seek for relatively small deposits and the Post Office is distinctly their rival for these, and he is therefore led to underestimate the immense faith of the English people in the solvency of the State. Last August, which rendered all banking assets except Cash-in-hand absolutely non-realisable, left the Post Office depositor unmoved, and the National Debt Commissioners seem justified in their opinion that "in a crisis great enough to shake it" (i.e., confidence in the Savings Bank) "recourse would certainly have to be had to paper currency." It is pertinent to ask, however, if such a crisis ought not to have been prepared for by the provision not of a gold reserve but of a ready printed paper currency.

Again, in comparing the large reserves held by the Continental National Banks with that held by the Bank of England it seems to the writer of this review that not sufficient account is taken of the different nature of their populations from an economic standpoint. Continental nations still contain a large peasant population, and to the peasant the ordinary currency is still a store of value, a thing it has practically ceased to be in this country. People in this country only think of the value of the note or coin next day or next week and are not therefore 
likely to refuse anything which is clearly legal tender. The peasant still saves partly by hoarding, and in times of crisis is always liable to return to it, especially where there is the memory of invasion. Moreover, the danger is greater because the peasant is largely self-sufficing. This point was brought home with great vividness to the writer, who happened to be staying at a small mountain chalet in Switzerland on the outbreak of war. The peasants immediately refused to accept paper money of any kind or to give change or credit. Now, had the artizans or shopkeepers in England behaved thus, a person of common sense would have preserved his equanimity, because in our system of society anyone refusing available currency would soon be starving. But one had an uncomfortable feeling that if the peasants wished to behave foolishly they at least would not starve and the occupants of the chalet counted their coins anxiously and looked with some affection at the domestic fowls. The panic was short lived, but the incident showed clearly that the danger of hoarding by a peasantry which is self-sufficing is infinitely greater than of an industrial population doing so. Therefore the centralising of the gold supply is more necessary on the Continent than in this country, where the bulk of it could always be quietly and effectively withdrawn from circulation through the agency of the banks.

The question of the gold reserve has entered on a new phase since last year. Events have shown that the danger of a sudden drain on the outbreak of war need not have been feared on account of London's position as financier and creditor of the world. That some people had not acted up to their own theories, even if those theories were wrong, did perhaps heighten the difficulties of last year's crisis. The difficulty with which we are now faced of being temporarily a debtor nation was naturally not foreseen, still less that the question of unduly trenching upon our ultimate reserve, namely our immense foreign investments, could ever become serious. In fact the course of events has made the critical part of Dr. Hulftegger's book valuable more as history than as criticism, but we hope that he will fulfil the promise of his preface and bring both his narrative and his criticism up to date.

In conclusion it must be noted that besides the statistics already mentioned "Die Bank von England" has an excellent appendix containing, among other things, a short chronological summary of the chief events in the Bank's history and tables comparing the rates of discount of the principal National Banks of Issue from 1844 to the present day. 
Finally, it will be an additional recommendation to many English readers that Dr. Hulftegger's book is written in extraordinarily clear and straightforward German.

Mabel C. Buer

Finance in China. Chinese Currency and Banking. By SRInivas R. WAGel. (Shanghai : North China Daily News and Herald. Vol. I. Pp. 503. 1914. Vol. II. Pp. 457. 1915. Price 18s. net each volume.)

THESE two bulky tomes represent an attempt to make a comprehensive survey of the economic conditions of China as they exist to-day; a laudable endeavour, but one that was sure to fail from the sheer magnitude of the task. Other preachers on things Chinese have devoted whole books to parts of the subject upon which Mr. Wagel has written only a few pages, and if we add to this the author's confession that the order of the topics was not determined by any settled plan we need not be surprised to find his acknowledging in the second volume that this plan-we had almost said "plot"-has been laid on too large a scale. The scope of the original work has consequently to be considerably widened, and with delightful naiveté the writer informs us that he has in preparation two additional volumes; one to deal with Taxation in China, the other with its Industries and Agriculture.

The financial history of China, in so far as her relations with the Western hemisphere are concerned, is chiefly the history of her foreign loans. The first foreign loan was floated in 1865, the lenders Russia; and since that date there has been, as the author implies, a succession of the most extraordinary and unproductive loans in the history of any nation. Extraordinary because of the political questions and rivalry which the negotiations have engendered among the great Powers; unproductive because of the wasteful manner in which the loan funds have been frittered away. In this connexion these volumes seem to be written with a good deal of inside knowledge, fortified with information which has been made public as the result of internal dissensions among the Chinese statesmen in authority and "old jealousies among the lending syndicates"; but, although such details form an instructive record of the Chinese incursion into the realms of haute finance, we doubt the wisdom of burdening an economic treatise with a tale of woe which had far better be forgotten. Mr. Wagel's righteous indignation has the effect, No. 99.- - vou xxv. 